\title{
Building the Islamic state \\ From ideal to reality (1947-1949)
}

\begin{abstract}
After much preparation, during the 20th gathering of the Dewan Imamah in Cimampang, with the attendance of Kartosuwiryo, K.H. Gozali Toesi, Sanoesi Partawidjaja, Raden Oni, and Toha Arsjad, on 7 August 1949 the Negara Islam Indonesia is officially proclaimed with the words: Proclamation of the Establishment of the Islamic State of Indonesia [NII],

Dengan Nama Allah, Jang Maha Esa dan Jang Maha Asih, we, the Islamic Community of the Indonesian Nation announce the establishment of the Negara Islam Indonesia.

And the law that governs the NII is Islamic Law. ${ }^{1}$
\end{abstract}

The 1947 invasion of West Java pushed Masyumi to proclaim resistance against the Dutch a jihad obligatory for all Muslims. Following the discord over the Linggadjati Agreement Sjahrir was forced to resign, then Masyumi refused to join Sjarifuddin's 'socialist' cabinet, and by late September tensions could no longer be confined to the political field, as they spilled out among the population and onto the battlefield. The violence that had dotted West Java throughout 194647 further escalated, even as the Indonesian Republic in Yogyakarta and the Dutch embarked on another round of diplomatic talks.

The Renville Agreement, signed by Van Mook and Sjarifuddin on 17 January 1948, was the outcome of heavy pressure from the United States and the United Nations. The international community had been lobbying to find a diplomatic end to the impasse caused by the military invasion on Java and Sumatra and to establish a roadmap for Indonesia's self-government. The agreement established that West Java (with the exception of the Banten area) and the easternmost part of Java (including Surabaya and Malang) would be officially controlled by the Dutch, whilst the rest of the island would constitute the territory of the Indonesian Republic. ${ }^{2}$

1 Qanun asasy Negara Islam Indonesia, AABRI DI no. 9.

2 'Situation in Indonesia truce agreement and "Renville" principles, Consul-General Shepherd to Mr. Bevin', in Correspondence part 2 January to December 1948, p. 3 onwards, FO $480 / 2$, NAUK. 
The separation of West Java from the Republican territory and the presence of Hizboellah and Sabilillah troops beyond the Van Mook demarcation line were crucial to the further shaping of the Darul Islam and Tentara Islam Indonesia in the early months of 1948. West Java was coming under Masyumi's control, and the Republican police (Kepolisian Negara)accused the Islamic party of challenging the Republic on the political and military levels.

These accusations were formulated at the same time as the West Java branch of the Islamic party was gradually being transformed into the Darul Islam organization. ${ }^{3}$ Kartosuwiryo's decision to pursue this transformation resulted from a combination of factors: the Dutch increase in activity in the Priangan between the end of December 1947 and mid January 1948; ${ }^{4}$ the withdrawal of TNI Siliwangi soldiers from West Java to Yogyakarta to be completed by March 1948; the Islamic militias' refusal to evacuate the region and their merger into one umbrella organization; the tensions between the TNI and the militias in the weeks leading up to the withdrawal; the scarcity of available weaponry; and the broad popular support for the Islamic militias. These factors strongly contributed to the shaping of the anti-Dutch resistance in West Java as an Islamic movement under Kartosuwiryo's leadership.

This chapter follows the formation of the Islamic State of Indonesia, from its initial conception in late 1947 to the proclamation of its establishment in August 1949, paying a great deal of attention to the interaction between the Darul Islam and Soekarno's Republic. The material is thus arranged chronologically, identifying four phases in this process. The first phase stretched from November 1947 until May 1948, when Kartosuwiryo, Oni and Kamran unified Hizboellah and Sabilillah into one Islamic Army, giving initial shape to the Darul Islam organization as a defence movement that sought the cooperation of the Republican Army (until its withdrawal from West Java), and led the expansion of Darul Islam control over the Priangan.

The next phase covers the second half of 1948, when the Darul Islam formed a ministerial cabinet, marking the transformation

3 As early as December 1947, Said Soerianatanegara (vice-chief of police in North Tasik) pointed out that Masyumi was increasingly resembling an independent state in the Priangan, undermining the authority of the Republic; see 'Perihal: Politieke situasi', 9 December 1947, KepNeg no. 495, ANRI.

4 In their effort to bring the region under control, the Royal Netherlands Indies Army had targeted several villages around Kuningan and Tasikmalaya. A detailed description of the attacks can be found in 'Laporan tentang keadaan didaerah Karesidenan Priangan, Kantor Kepolisian Karesidenan Priangan', 28 February 1948, KepNeg no. 495, ANRI. For reports of how the Dutch ransacked civilians' houses, stole livestock and bombarded villages, see 'Politiek-Economisch Verslag betreffende de Residentie Priangan over de maand December 1947', 2 February 1948, AMK:RI no. 328, NA. Sabilillah also took revenge on those who did not support Masyumi; see 'Laporan tentang keadaan didaerah Karesidenan Priangan, Kantor Kepolisian Karesidenan Priangan', 28 February 1948, KepNeg no. 495, ANRI. 
of the Majelis Oemmat Islam from a socio-political movement to a government body. During this time, Kartosuwiryo released the Constitution of the NII. With Muhammad and Medina as his models, Kartosuwiryo chartered a country - the Negara Islam Indonesia - built around the authority of a leader who embraced the spiritual, political and military legacy of the Prophet. It ought to be noted that at this point the NII still sought to collaborate with the Yogyakarta Republic, sharing the common goal of national independence. It was not until the third phase, from the second Dutch invasion in December 1948 to the Roem-Van Royen Agreement in May 1949 that frictions emerged, eventually leading to the antagonism between the Islamic Army and Siliwangi soldiers and to their ultimate parting of ways.

The last phase analysed here covers the August 1949 proclamation of the Islamic State of Indonesia as a political entity independent from Soekarno's Republic. This phase thus also takes a look at the first attempts of the Masyumi-led cabinet to negotiate with Kartosuwiryo. In fact, despite the continued antagonism on the battlefield, Natsir and some TNI commanders showed sympathy for the Darul Islam, and throughout 1949 the Masyumi-led cabinet strongly supported a political solution to the 'Darul Islam problem'.

GROUNDWORK (NOVEMBER 1947-MAY 1948)

\section{Imagining the Islamic state (November 1947-January 1948)}

The first step in the formation of an Islamic resistance organization and an Islamic army in West Java - later to be known as Darul Islam, Tentara Islam Indonesia and Negara Islam Indonesia - was probably taken in late 1947, when Kartosuwiryo, as vice-president of Masyumi for West Java, called for a conference to re-organize the party's constituency. ${ }^{5}$ Masyumi's membership in the province

5 According to 'Negara Islam', Territoriaal Troepencommandant West Java, 12 June 1948, APG no. 997, NA, this meeting took place in September 1947; according to 'Majelis Oemat Islam', 'C' Divisie '7 December', 12 August 1948, APG no. 997 NA, and Centrale Militaire Inlichtingendienst [hereafter CMI] Publication no. 91, 29 September 1948, AAS no. 3977, NA, this meeting instead took place in November 1947.

The Islamic community of West Java was also being organized within the context of the creation of the state of Pasoendan (itself part of the scheme for a Republik Indonesia Serikat (RIS, Federal Republic of Indonesia), as in mid October the Islam Conference established the dewan agama (religious council) and dewan al-Islam (Islamic council), which included a mahkama Islam, penghulu hakim, hakim nikah (Islamic court, Islamic judge. and marriage officer, respectively), and an educational division, thus covering all needs of the ummah. 'Islamic conference of West Java', 26-29 November 1947, AAS no. 3405, NA; this was followed by a similar initiative in East Java. 
was divided into five regional branches - Priangan, Banten, Jakarta, Bogor and Cirebon -, each sub-divided into provincial and villagelevel branches (cabang and anak cabang, respectively). The cabangGarut was at the centre of the party's initial transformation in the region, a fact made clear when it changed its name into Majelis (or Dewan) Pertahanan Oemmat Islam (MPOI/DPOI, or Islamic Community's Defence Council).

In order to integrate different constituents into a single body, the party's multiple armed wings, including Sabilillah, Hizboellah, Gerakan Pemoeda Islam Indonesia (GPII, Indonesia's Muslim Youth Movement) and other youth groups, were merged into a single army, the Tentara Islam Indonesia. ${ }^{6}$ Around the same time, Kartosuwiryo and his aides added a new article to the party's programme to further stress the adjustments necessary under their current state of war and struggle, namely, that they had the duty to 'defend [the territory] from the attacks of the Royal Army'. ${ }^{7}$ Though the TII had become a reality both on paper and as a military body for Kartosuwiryo and his lieutenants, soldiers themselves had not yet been organized around a comprehensive strategy.

In accordance with the Renville Agreement, TNI troops were ordered to evacuate West Java by the end of February 1948. In the weeks between the signing of the agreement and the beginning of the withdrawal, Republican and Islamic soldiers often clashed. Tensions were inflamed by a number of factors, including the troops' different attitudes to combat and their scarcity of weapons, as already discussed. Islamic soldiers accused TNI soldiers of 'sitting around', waiting to withdraw without engaging in battle, and of not making good use of their rifles, whilst the Sabilillah and Hizboellah militias were exposing themselves to harm even without the appropriate equipment. $^{8}$

Feeling the need to optimize their efforts and limit the clashes within the anti-Dutch front, Hizboellah, Sabilillah, Masyumi and TNI chiefs agreed to a meeting that would be mediated by local

6 As it will become evident below, other sources claimed that the Tentara Islam Indonesia was created in February 1948. However, it is possible that already by late 1947 the coordination efforts among Islamic militias in West Java had led to the formation of a unified army.

7 'Majelis Oemat Islam', 'C' Divisie '7 December', 12 August 1948, APG no. 997 NA. Probably it referred to the KNIL, but the report only talks of 'Nederlandse Leger' and 'Tentara Keradjaan'.

8 One such clash, for example, occurred in Sukasari (Maja); here two Hizboellah battalions that had arrived from Gegesik (Indramayu) in January were attacked by the TNI after they had been caught stealing weapons. 'Perlutjutan sendjata terhadap TNI oleh Hizboellah, Kantor Polisi Kabupaten Madjalengka', 19 January 1948, KepNeg no. 565, ANRI. 
civilian authorities in Majalengka, which in early 1948 was the hub of military activities in the Priangan. The meeting did not achieve the intended goal of creating a unified army, but the participants at least recognized the need for coordinated action.

On the one hand, Islamic militias formally complained about the inertia of Republican soldiers and requested that other irregular militia groups be incorporated into their own ranks, rather than into the TNI's. On the other hand, TNI commanders diplomatically suggested that their units should simply withdraw to Yogyakarta and surrender the defence of Majalengka to Hizboellah, as having 'two armies in one state' only created friction. Eventually, the parties agreed to arrange another meeting, in which higher officials would participate. TNI was to be represented by Lt. Col. Abimandju and Col. Hidayat (second-in-command of the Siliwangi Division), Masyumi by Kartosuwiryo, and the militias by Kamran (chief of West Java Sabilillah troops stationed in Bantarujeg, south of Majalengka). ${ }^{9}$ The prominent place given to them in this meeting confirms Kartosuwiryo's and Kamran's leading roles in the province.

It is interesting to note that the source refers to Masyumi and Sabilillah instead of MOI or TII, suggesting the possibility that until February-March 1948 Sabilillah and Hizboellah may have been coordinating their activities under the command of the MPOI/ DPOI, and that the Darul Islam/Tentara Islam Indonesia 'proper' was only established in March 1948.

Even though sources on the second meeting are scattered, evidence suggests that it was held in Cinta, a village under Mount Talagabodas (Sukawening), just before the Siliwangi soldiers' withdrawal in late January 1948. This meeting saw the participation of Col. Hidayat, Major Utaryo, Kartosuwiryo and several civil servants from West Java. On this occasion, Kartosuwiryo expressed his opposition to the TNI's retreat and suggested that they all wage a holy war against the Dutch. What is more, he requested that Siliwangi soldiers leave their weapons behind to be used by those who were ready to fight the Dutch, meaning the Islamic troops. ${ }^{10}$

9 The mediating civilian figures were the mayor of Majalengka, the people's representative and the local chief of police. 'Perlutjutan sendjata terhadap TNI oleh Hizboellah, Kantor Polisi Kabupaten Madjalengka', 19 January 1948, KepNeg no. 565, ANRI.

10 Edi S. Ekadjati, Sejarah kebangkitan nasional daerah Jawa Barat (Jakarta: Proyek Penelitian dan Pencatatan Kebudayaan Daerah Jawa Barat, Pusat Penelitian Sejarah \& Budaya, Departemen Pendidikan dan Kebudayaan, 1979), p. 207. The two requests mentioned above are also said to having been put forward by Oni and Kartosuwiryo in January 1948; see 'Tanggal2 bersedjarah bagi gerombolan D.I'. [1952?], AABRI DI no. 14. 
These demands were rejected by the TNI, and by the beginning of February 1948, roughly 22,000 men - and their weapons - were already on their way to Yogyakarta under the command of Colonel Nasution. ${ }^{11}$ Though Indonesian forces outnumbered them, the militias had by now made it clear that they did not intend to leave. Several thousand Hizboellah and Sabilillah militiamen remained in West Java, swelling the numbers of Kartosuwiryo's DI-TII. ${ }^{12}$

During the first week of February 1948, officials of the state of Pasoendan (Negara Jawa Barat) took steps to convince regional Masyumi leaders to surrender their weapons and join the state. The list included several popular and military leaders from Tasikmalaya, Garut and Ciamis, amongst whom were Kamran, Toha Arsjad, Joesoef Taoeziri and Junaidi, but not Kartosuwiryo. ${ }^{13}$

\section{Laying the foundations of the Islamic state (february-march 1948)}

According to a 1953 RI government publication, Kartosuwiryo received very little support in his endeavour to create an Islamic state. It is there argued that the majority of those present at the initial gatherings rejected the project of creating an Islamic state in West Java on the grounds that doing so would "create a dubbelstaat, a state within the state. ${ }^{14}$ However, archival sources paint a different picture.

As the Siliwangi soldiers prepared to withdraw, Kartosuwiryo and other Masyumi and Sabilillah officers followed up on their earlier attempts to coordinate Islamic resistance to the Dutch by organizing a conference in Pangwedusan, Cisayong. ${ }^{15}$ On 10-11 February 1948, some five hundred delegates and members of five Masyumi branches from across West Java (Tasikmalaya, Garut, Kuningan,

11 Abdul Haris Nasution, Tentara Nasional Indonesia (Jakarta: Seruling Masa, 1968); Ricklefs, A history, p. 227.

12 By the end of the year more than 50,000 men were in the rank and file of the TII. 'CMI Doc. No. 5176, Documenten betreffende de "Daroel Islam”-beweging', 21 December 1948, AAS no. 2752, NA. Among them were Zainal Abidin's group in Blubur Limbangan, Koernia's in Cicalengka, Enoks's in Wanaraja (Garut), Oni's in Mount Cupu, and Kamran's on the border between Majalengka and Tasikmalaya (Pagerageung area). Nasution, Tentara Nasional Indonesia, p. 125; Tanu Suherly, 'Kekuatan gerilya di daerah Priangan pada waktu divisi Siliwangi hijrah tahun 1948'. Paper, Seminar Sejarah Nasional ke-3, Jakarta, 10-14 November 1981, p. 4. This second source provides a detailed list of the various groups on pp. 4-10.

13 'Onderhandelingen met Masjoemi', 9 February 1948, AAS no. 2746.

14 Kementerian Penerangan, Republik Indonesia: Propinsi Djawa Barat (Jakarta: Kementerian Penerangan, 1953), p. 215.

15 Dinas Sejarah TNI, Penumpasan pemberontakan D.I./T.I.I., pp. 59-65. 
Majalengka and Ciamis), as well as representatives of Persis, Nahdatul Ulama and Muhammadiyah attended the conference, the explicit aim of which was to establish an Islamic state and army. ${ }^{16}$

These party leaders suspended the activities of the West Java branch of Masyumi and agreed on a plan to draft a clearly defined Islamic policy, create an army and elect a leader. Kartosuwiryo was nominated imam of the Islamic community in West Java, and Oni chief of the Indonesian Islamic Army in the Priangan. Although most of these actions were not initiated until after the March conference (see below), this meeting had already stated the intention of establishing an Islamic state that would implement Islamic laws in the daerah istimewa (special region) between Pagerageung, Cikoneng and Mount Sawal. It also declared a holy war and transformed the Sabilillah into the Tentara Islam Indonesia. ${ }^{17}$

The February meeting was followed by another conference, held on 1 March in Cirebon. Between January and mid March the press recorded a rapid increase in Islamic militias in the Priangan. Until January the town of Maja had been hosting an average of around 300-600 Hizboellah soldiers, but in late February more than 2,000 Hizboellah soldiers, who had been stationed in the area, attacked Bandung, Maja, Majalenka, Sukahaji and Kadipaten. In mid March the Dutch 'W' Brigade noted a 'large concentration' of Tentara Islam, and by April around 3,000 Hizboellah soldiers under the command of Oni and Lubis were in the area. ${ }^{18}$

At the Cirebon conference, Imam Kartosuwiryo, together with Kamran and Raden Oni (heads of the military section), Sanusi Partawidjaja and Toha Arsjad (leaders of the political section) and Kiyai Abdul Halim and Kiyai Haji Gozali Toesi (of the religious section), created the political and military structures needed to confront the Dutch. ${ }^{19}$ First, they announced the dissolution of Masyumi and the suspension of its activities in West Java. In July 1948 the Yogyakarta chief of police speculated that behind Kartosuwiryo's dissolution of Masyumi was antagonism regarding Soekiman's 'not

16 Dani Wahdani, 'Politik militer Angkatan Perang Negara Islam Indonesia (A.P.N.I.I.) di Jawa Barat pimpinan Imam S.M. Kartosoewirjo' (thesis, Universitas Padjadjaran, Bandung, Jatinangor, 2003) p. 59, quoting from Sedjarah Goenoeng Tjoepoe.

17 'Overzicht en ontwikkeling van de toestand 8 April 1800 uur tot 15 April 1800 uur', Territorial ts. Troepencommandant West Java [1948], MD: AS no. 2224, NA.

18 'Sabilillah liar bergerak di sekitar Tjamis', Sin Po, 1 March 1948, and 'Hizbullah moendoer ke Goenoeng Tjiremei', Keng Po, 1 April 1948. See also MD:AS nos 2275 and 2288, NA.

19 Dinas Sejarah TNI, Penumpasan pemberontakan D.I./T.I.I, p. 63. Some degree of influence was also in the hands of Dahlan Lukman (GPII-Priangan leader), Siti Murtayi'ah (GPII-Putri Priangan leader), Abdullah Ridwan (Hizboellah-Priangan leader) and five other cabang-level leaders from Garut, including Saefullah (cabang vice-president), who was subsequently arrested and on whose confessions the first Dutch report on the Darul Islam was based. 
radical enough' leadership of the party. ${ }^{20}$ However, the Masyumi leaders who were gathered in Cirebon declared that it was time for Masyumi to terminate its operations in West Java because of the 'general situation in the region':

Especially as the political negotiations between the Republican government and the Netherlands are not concluded yet, all Masyumi's subgroups $[\ldots]$ and all the organization's branches are to suspend their activities in the western part of Java beginning 1 March 1948 at 14.00.

The announcement also specified that anyone who had previously held representative roles would no longer have the right to speak for Masyumi, nor for any of its sections. ${ }^{21}$

The various militias were merged to form a unified and structured army - the Tentara Islam Indonesia - which would operate under the command of Kamran on the western side of the Van Mook line. ${ }^{22}$ This army was instructed to "come to power in a tactful way, succeed in taking control of the Republic, and include it [s territory] within the Islamic state'. ${ }^{23}$ The political agenda of this new organization was focused on the preparations for a new state, a Negara Baru. This 'New State' would be a democratic Islamic state, the existence of which was seen by its founders as an alternative solution to a national state in case the Republican government were dissolved, or a Dutch-promoted state of West Java created. ${ }^{24}$

All matters related to combat were to be determined by the Islamic government in accordance with 'Islamic laws', ${ }^{25}$ but no further details are provided. The participants at the March meeting agreed on a list of actions to be pursued in the immediate future to oppose Dutch domination and to strengthen Islamic piety in the area. ${ }^{26}$ The last concern addressed at the meeting was the West Java Islamic community's need for a unified leadership, a problem solved by the election of Kartosuwiryo as sole commander of the ummah in the region and his confirmation as $\mathrm{imam} .{ }^{27}$

20 'Darul Islam di Djawa Barat', Djawatan Kepolisian Negara Bagian PAM Yogyakarta, 23 July 1948, JogjaDoc no. 203, ANRI.

21 'Dunia Masyumi menghentikan usahanya', 1 March 1948 in 'Pelaporan No. 14/7/48 Perihal Darul Islam', Jawatan Kepolisian Negara Bagian PAM Yogyakarta, 17 July 1948, JogjaDoc no. 218 h, ANRI.

22 'Rencana ketentaraan oemmat Islam', in JogjaDoc no. 218h, ANRI.

23 'Dunia Masyumi', in JogjaDoc no. 218h, ANRI.

24 'Program politik ummat Islam', in JogjaDoc no. 218h, ANRI.

25 'Rencana ketentaraan oemmat Islam', in JogjaDoc no. 218h, ANRI.

26 'Daftar usaha cepat', in JogjaDoc no. 218h, ANRI.

27 'Kesatuan pimpinan', in JogjaDoc no. 218h, ANRI. 
Possibly because of the increasing presence of Islamic militias in the Priangan area, or possibly because of the geographic spread and high profile of its participants, the Cirebon gathering attracted the attention of the Dutch authority and the Republican police alike. As early as April, the Republican police and the Dutch reported on Masyumi's new military configuration in the Ciamis, Mount Sawal and Mount Cupu areas and its relation to the Darul Islam/Tentara Islam Indonesia, ${ }^{28}$ describing this new group as a puritan Islamic movement aimed at the establishment of an Islamic state. ${ }^{29}$

Reportedly, the March gathering was attended by branch leaders from Bandung, Sumedang, Tasikmalaya and Ciamis. The Cirebon regional branch of Masyumi decided to adhere to Kartosuwiryo's transformation; Banten and Jakarta refused the offer, at least for the time being, while Bogor made it clear that it wanted to wait for the result of the Renville plebiscite. ${ }^{30}$ The Plebiscite Movement demanded a popular consultation to determine whether Java, Madura and Sumatra would be part of the Yogyakarta Republic or would instead create their own states within the federal structure.

Even though they initially appeared to have lukewarm feelings about the idea, in May 1948 the Banten branch (which included some government representatives) issued intense public propaganda in support of the Darul Islam and against the Republican government, ${ }^{31}$ and in August the head of the Majelis Islam in Bogor, Raden Mohammad Sapri, was arrested for forming a TII branch. ${ }^{32}$

In March the established 'Islamic government' was called Majelis Oemmat Islam, a variation on the Garut Islamic Community's Defence Council, MPOI. In the previous months the MOI had been replicated across the region, forming a network of local 'Islamic councils' through which Islamic leaders coordinated the defence of West Java and formed an Islamic mass movement

28 'Beknopt Politiek-Politioneel Verslag van de regentschappen Bandoeng, Garoet, Tasikmalaja, Tjiamis, Soemedang, Cheribon, Koeningan, Indramajoe, Madjalengka, Poerwakarta, Soekaboemi, Tjiandjoer en Buitenzorg, over de maand Maart 1948'; and 'Politiek-Economisch Verslag betreffende de Residentie Priangan over de maand Maart 1948', 28 April 1948; both in AMK:RI no. 283, NA.

29 'Politiek-Economisch Verslag', 28 April 1948; and 'Beknopt Politiek-Politioneel Verslag van de regentschappen Bandoeng, Garoet, Tasikmalaja, Tjiamis, Soemedang, Cheribon, Koeningan, Indramajoe, Madjalengka, Poerwakarta, Soekaboemi, Tjiandjoer en Buitenzorg, over de maand April 1948; both in AMK:RI no. 283, NA.

30 'Majelis Oemat Islam', 'C' Divisie '7 December', 12 August 1948, APG no. 997 NA.

31 'Extract uit D.O.B.I. n.631 dd 10/05/48 Nefis IV dd 9-5-48 Eval A.Z.', APG no. 1000, NA.

32 'Tentara Islam Indonesia', 17 August 1948, APG no. 1002, NA. 
dedicated to creating an Islamic state. ${ }^{33}$ Between early 1948 and the official proclamation of the Negara Islam Indonesia in August 1949, the MOIs functioned as party branches representing local headquarters of the Darul Islam and coordinating the activities of Masyumi, Sabilillah, Hizboellah and GPII across the island (mostly between West and Central Java). ${ }^{34}$ Notably, in September 1948 the Republican police in Yogyakarta still considered these MOIs to be pro-Republican. ${ }^{35}$

Even though the MOI structure was not gathering much institutional support from Masyumi, the more general goal of creating an Islamic state was shared by a number of party leaders, who were also influenced by international events. When Israel, for example, was recognized as a state in Palestinian territory in May 1948, the Dutch government became concerned that the Palestinian question would become yet another piece of the Islamist puzzle in Indonesia, pushing Masyumi leaders towards further action. It is worth noting that the report explicitly singled out Soekiman, Kasman Singodimedjo, Abikoesno, Wondoamiseno, Agoes Salim, Aroedji Kartawinata, K. Ahmad Sanoesi and Kartosuwiryo as politicians who would be particularly sensitive to developments in the Middle East. ${ }^{36}$ Indeed these events stirred much interest in Masyumi and Darul Islam circles.

At the 1948 Masyumi congress, held on 28 March in Madiun, Wali Alfatah (who would, in November, become vice-chairman of the Central Board) and Kiyai Ahmad Sanoesi (member of the National Majelis Sjoero) issued a joint declaration in favour of the creation of a dar-ul-Islam 'as soon as possible' in order to end the armed national revolution. The congress had gathered after the formation of the DI-TII, and the head of the NII's information office in Tasikmalaya, Abdoelhadi Ibrahim, was present at the congress as Darul Islam's representative. However, neither Wali Alfatah nor Kiyai Ahmad Sanoesi made any reference to Kartosuwiryo. ${ }^{37}$

33 Qanun asasy Negara Islam Indonesia, AABRI DI no. 9.

34 'Ontstaan en ontwikkeling der 'Majelis Islam', bezien uit militair standpunt', Territoriaal Troepencommandant West Java, 19 March 1949, APG no. 1002, NA.

35 'Surat dari Jawatan Kepolisian Negara bagian PAM tentang skema dari partai-partai yang dalam perjuanganya menentukan sikap pro dan anti-pemerintah', 9 September 1948, JogjaDoc no. 233, ANRI.

36 'Hr.TOL' (untitled), 21 May 1948, APG no. 1005, NA.

37 'Darul Islam di Djawa Barat', Djawatan Kepolisian Negara Bagian PAM Yogyakarta, 23 July 1948, JogjaDoc no. 203, ANRI, states that 'the characteristics of the Darul Islam survive also amongst Masyumi circles in the Republican territory, as evidenced in the speeches of Wali Alfatah and Kjai A. Sanusi'. This is the first instance in which the DI-TII is ignored as a model by other Islamic leaders advocating for an Islamic state; the reasons for and consequences of this attitude are further discussed in Chapter 6. 
Although they both argued in favour of an Islamic state, the speeches reflect the well-established difference between modernists' and traditionalists' strategic approaches to the creation of an Islamic state, as one focused on society and the other on institutions as primary engines of the transformation.

Sanoesi doubted that a dar-ul-Islam could be established in Indonesia because of the limited support enjoyed by Masyumi among peasants and labourers. Openly challenging Soekarno's Pancasila philosophy, Sanoesi stated that Masyumi's aim could only be achieved if the three fundamental elements of the state - the people, the government and the laws - were Islamic. On the other hand, Wali Alfatah expressed a more optimistic view of the future position of Islam in Indonesian politics, as he trusted that Soekiman, as Minister of the Interior, would exert pressure on the civil servants to return to the occupied areas of the Republic and proclaim an Islamic state. ${ }^{38}$ It is perhaps on these grounds that in April the Dutch suggested that Soekiman was the leader of the Darul Islam. ${ }^{39}$

The Pasoendan State, as noted above, had been trying to co-opt regional Masyumi leaders into their Negara Jawa Barat project, in February 1948. The president of this state, R.A.A. Wiranatakoesoema, had demonstrated an interest in realizing an Islamic political option for independent Indonesia as early as March 1947, and in April 1948 he participated in the formation of the MPOI in Bandung, for which he had shown open support. As the Islamic national movement in West Java assumed structural shape and increased its territorial control (see below), Kartosuwiryo decided to approach Wiranatakoesoema to suggest that they engage in a common struggle to ensure that West Java's independence would be established in Islamic terms. When directly contacted by Kartosuwiryo in August 1948 and by the Tentara Islam Indonesia in late February 1949, however, Wiranatakoesoema appeared reluctant to cooperate. ${ }^{40}$

Aside from these political reactions to the re-structuring of Masyumi, another key player in the success of the Darul Islam

38 'Kutipan Pidato2 pada tgl 28/3-'48 (Kongres Masjumi di Madiun) dari 1. Wali Alfatah 2. KA Sanoesi', JogjaDoc no. 243, ANRI.

39 'Daroel Islam', 5 June 1948, APG no. 1002, NA.

40 'CMI Signalement: de verhouding tussen Wali Negara van Pasoendan Wiranatakoesoema en de Daroel-Islam', March 1949, AAS no. 3979, NA. Interestingly, an earlier Dutch document argued that Darul Islam troops were actively opposing the Negara Pasoendan project in favour of a state truly independent of Dutch influences; see 'Beknopt Politiek-Politioneel Verslag van de regentschappen Bandoeng, Garoet, Tasikmalaja, Tjiamis, Soemedang, Cheribon, Koeningan, Indramajoe, Madjalengka, Poerwakarta, Soekaboemi, Tjiandjoer en Buitenzorg, over de maand April 1948', AMK:RI no. 283, NA. 
was the local population. Local villagers in the Priangan openly endorsed Islamic militias' activities and supported them in their struggle, to the point that TNI soldiers often complained about this favouritism. ${ }^{41}$

\section{Initial expansion (March-May 1948)}

As mentioned above, the numbers of Islamic militias in the Priangan swelled from a few hundred to a few thousand in the short span between the beginning of the Siliwangi withdrawal until the end of March. This increase in number soon had consequences, especially as Hizboellah and Sabilillah were not the only irregular troops in the area, and the regular TNI had not completely evacuated the region.

In addition to clashing with TNI soldiers over weapons and supplies, throughout 1948 the troops of the Islamic Army also became engaged in a struggle to expand the territorial scope of the MOI-controlled areas at the expense of other guerrilla groups and the Dutch.

As territorial expansion had become a strategic priority, Kartosuwiryo and his military aides had divided West Java in three areas, depending on the degree of control that the Majelis held. The Daerah Satu (shortened in the original documents as D.I and meaning Region One) included villages controlled by the Darul Islam and implementing Islamic law. The Daerah Dua (D.II, Region Two) included the areas where the Darul Islam, the MOI or the TII had freedom of movement and strong influence. Lastly, the Daerah Tiga (D.III, Region Three) included those areas where the Darul Islam only had a limited degree of influence.$^{42}$ According to this organizational scheme, in May 'Region One' included the area enclosed within Tasikmalaya, Ciawi, Panumbangan and Mount Sawal; the D.II encompassed the area between Cileungiji (Ciamis), Cisayong (Tasikmalaya), Nagrek, Darmarata, Talaga and Mount Sawal; and the D.III stretched eastward to Majalengka and Cikijing, and southeast to Lakbok, Parigi, Cikatomas and Tasikmalaya. ${ }^{43}$

The Dutch attempt to cleanse Mount Sawal's surroundings of Islamic fighters created considerable difficulty for the militias' operations, but at the same time it provided the fighters with renewed

\footnotetext{
41 'Tindjauan singkat tentang keadaan daerah Keresidenan Prijangan', 31 March 1948, KepNeg no. 495, ANRI.

42 Qanun asasy Negara Islam Indonesia, AABRI DI no. 9; 'Majelis Oemat Islam', 12 August 1948, APG no. 997, NA, pp. 6-7; CMI Publication No. 91, 29 September 1948, AAS no. 3977, NA, pp. 8, 13.

43 CMI Publication No. 91, 29 September 1948, AAS no. 3977, NA.
} 
strength and motivation. In retrospect, Dutch efforts to purge the Darul Islam from the Priangan were highly ineffective and mostly counterproductive. The Dutch Army had dispersed Islamic troops in Cikatomas, but this only resulted in the splitting of the militias between Cikalong (to the south) and Leuwisari (to the north). Similar attacks on the Mount Cupu area had spread Darul Islam soldiers to Cisayong, Ciawi, Indihiang and the southern districts. Further, Darul Islam troops had re-emerged in Pangerageung and Cineam, where they shared control of the territory with the communist Bamboe Roentjing militias. ${ }^{44}$

As a result of the successful political guidance of Kartosuwiryo and the able military leadership of Kamran and Nur Lubis, the Darul Islam expanded widely. By May 1948 the Majelis Oemmat IslamDarul Islam had established its territorial presence across the Priangan, while at the same time strengthening its political structure.

A STEP CLOSER TO ESTABLISHING THE ISLAMIC STATE

(MAY-DECEMBER 1948)

\section{Institutional and territorial consolidation}

In the second half of 1948, the Darul Islam's efforts were channelled into consolidating the movement's control over West Java and opposing the Dutch in both military and political capacities. In early May 1948 Kartosuwiryo, Sanoesi Partawidjaja, Kamran, Toha Arsjad, and Kiyai Gozali Toesi led a conference in the vicinity of Bantarujeg (Majalengka) to establish the majelis imamah or kabinet (guiding assembly, or cabinet), an act that marked the transformation of the MOI from a socio-political mass movement into a government body. ${ }^{45}$

On 27 August Kartosuwiryo released the Constitution of the Islamic state, and in the following months he continued to structure and give a clearer shape to this political entity. The Negara Islam Indonesia was to be a republic, led by an imam and based on sharia law. The imam had to be elected, his actions would be pursued only in the interest of the public and his authority would be submitted only to the sharia. He was entrusted with law-making, a process whose principle aim would be the formulation of laws

44 'Tjatatan ringkas dari laporan2 jang ketrima antara tanggal 22 sampai 31 Agoestus 1948 tentang kedjadian2 dalam kaboepaten Tasikmalaja', 1 September 1948, APG no. 1080, NA.

45 Dinas Sejarah TNI, Penumpasan pemberontakan D.I./T.I.I., p. 64. 
inspired by sharia principles and, at the same time, able to deal with the needs of a modern Islamic society.

Similar paradigms of government were suggested by other groups across the archipelago, especially in Aceh and South Sulawesi, as mentioned in the preface to this book. Yet, despite having a vision starkly different from Soekarno's, the Darul Islam was still far from positioning itself in opposition to the Republic, keeping its focus instead on regional anti-Dutch activities. For the Darul Islam, the Islamic state was in a state of war, or jihad, with the Dutch forces, and every member of the Islamic ummah had the religious duty to fight $f i$ Sabilillah. ${ }^{46}$

July and August, which that year corresponded to the fasting month of Ramadhan, had been quieter than the rest of the year. Yet even amidst reduced clashes and increased arrests, the Darul Islam had nonetheless succeeded in consolidating its presence in the region. ${ }^{47}$ By the end of September 1948, the D.I area included the territory that had been under D.III in May. The D.II stretched southwest to Pameungpeuk and Mount Cupu, northwest to Tanjungsari and Tanjungkerta (Sumedang), north to the railway in Sukamelang, east to Cirebon, and then curving back in to Cikijing and Mount Sawal. The D.III had expanded further into the Garut regency in Bungbulang, towards Bandung, Indramayu and Cirebon in the north, and east into Central Java, with Salem under Darul Islam influence. ${ }^{48}$

The expansion towards the east was led by Amir Fatah, commander of the mobile division of the TII. Through October and December he would push into the neighbouring province and become head of the Central Java division of the Darul Islam. ${ }^{49}$ Here the Darul Islam won the support of smaller Islamic groups, including the Moedjahidin of Pekalongan, Tegal and Brebes, which then became the core of the local Darul Islam. ${ }^{50}$ In the west, the TII had regiments in Bogor, Jakarta and Banten as early as June 1948. ${ }^{51}$

46 'Maklumat Negara Islam Indonesia no. 1, 25 August 1948, JogjaDoc no. 218e, ANRI.

47 'Beknopt Politiek Politioneel Verslag van de regentschappen Bandoeng, Garoet, Tasikmalaja, Tjiamis, Soemedang, Cheribon, Koeningan, Indramajoe, Madjalengka, Poerwakarta, Soekaboemi, Tjiandjoer en Buitenzorg' for the months of July and August 1948, AMK:RI no. 284, NA. 48 CMI Publication no. 91, 29 September 1948, AAS no. 3977, NA.

49 'CMI Doc. No. 5176, Documenten betreffende de "Daroel Islam"-beweging', 21 December 1948, AAS no. 2752, NA.

50 CMI Publication No. 97, 18 November 1948, AAS no. 3977, NA.

51 'Rapport van Bk. Bandoeng inzake Islamitische stromingen in de residenties Priangan en Cheribon', Archief van de Marine en Leger Inlichtingendienst, Netherlands Forces Intelligence Service en Centrale Militaire Inlichtingendienst in Nederlands-Indië [hereafter AIntel] no. 1705 , NA. 


\section{Structuring the Islamic State}

According to a 1950 document drafted by the Ministry of the Interiors of the Indonesian Republic, on 13 October 1948 the leaders of Islamic organizations (including Anwar Tjokroaminoto and Abikoesno Tjokrosoejoso), national leaders (including Muhammad Natsir, Kasman Singodimedjo and Soekarno), and military commanders (including General Sudirman) were given copies of the Qanun asasy Negara Islam Indonesia, the Constitution of the NII. The compiler of the 1950 document mentions that these leaders had also received a request to provide moral and material support to the NII's struggle, but 'They were all warned by the events of Madiun and kept that as a learnt lesson', and thus refused to get involved with the Darul Islam. ${ }^{52}$ In the aftermath to the Siliwangi withdrawal to the Solo area, this TNI division clashed with antigovernment communist troops whose stronghold was in Central Java. In mid September, as political tensions escalated, PKI and Pesindo troops gathered in Madiun and took control of the city, proclaiming a National Front government (this is further discussed on p. 173).

The Constitution of the Negara Islam Indonesia is composed of fifteen chapters comprising a total of thirty-four articles. It deals with several aspects of creating and maintaining a state, paying particular attention to the structures of Islamic political authority. The constitution provides for the establishment of a parliament (majelis syuro), an executive committee (dewan syuro) and an advisory council (dewan fatwa). It considered matters regarding the powers of the national government, regional divisions, finance, the judiciary, rules of citizenship, matters of national defence, education, economy, flag and language, and procedures to amend the constitution. $^{53}$

Such structure closely resembles that of the Indonesian Republic's Constitution, and some of the more general matters regarding the state also seem to have been inspired by it. However, considering the historical understanding of qanun as a set of religious laws in accordance with the current time, it would not be fair to belittle the importance of this constitution as an Islamic text simply because of its concern with mundane aspects of politics and its parallels with a secular constitution. After all, Islamist ideologies 'are not con-

52 'Ichtisar gerakan DI/Kartosuwiryo', Kemeterian Dalam Negeri Yogyakarta, 24 July 1950, KabPerd no. 150, ANRI.

53 I have here used the text as it appeared in 'De grondwet van de Daroel-Islam', Ministerie van Binnenlandsche Zaken Negara Pasoendan, 26 October 1948, AAS no. 2752, NA. 
tinuous with historical Islam, but rather are modern constructions influenced by current conjunctions', as Sami Zubaida has argued in the case of the Islamic Republic of Iran. ${ }^{54}$

Together with the 1949 criminal code, this text remains one of very few attempts to formally structure an Islamic state in the Sunni Muslim world in the twentieth century, possibly only equalled by Nabhani's Nizām al-Islām, which was published in 1952 and is still today the blueprint for creating an Islamic state for the global Hizb ut-Tahrir movement.

Kartosuwiryo's Constitution opens with a preamble explaining the historical circumstances in which the Islamic state had come into being. The Renville Agreement is described as a blessing in disguise, as from then on the ummah of West Java, under the leadership of Masyumi, would lead a 'second revolution' of resistance in name of Islam - a jihad. Kartosuwiryo regarded the NII as a 'gift of God' (Kurnia Allah) to the Indonesian people. Formally a republic (in the text defined as jumhuriyyah and republik), this Islamic state saw the Qur'an and hadith sahih as the highest laws and believed it had the duty to enforce Islamic law on its community whilst ensuring freedom of religious belief and practice to all its citizens. The majelis syuro was entrusted with both the duty to elect the imam and the power to make laws, although in a state of emergency the imam and the dewan imamah (whose members were appointed and discharged at the imam's discretion) could take over. The imam's oath was to be given before parliament, acknowledging the paramount importance of acting for the benefit of Islam and the state. The imam was allowed to stay in office as long as he acted according to the sharia, fulfilled his oath, and governed in accordance with the teachings of Islam.

Kartosuwiryo insists on the figure of the imam. This Qanun gives the imam almost unlimited powers and authority, with the only limit being parliamentary approval in the law-making process. He would also have an advisory council, the dewan fatwa, composed of up to seven mufti and headed by one Great Mufti to guide him in his decisions. The imam had the rights to declare siege and war and to rule by decree. He was head of the armed forces; appointed and received ambassadors and consuls; decided on matters of amnesty, abolition of punishment, clemency and re-education; and conferred titles, decorations and honours.

54 Sami Zubaida, 'Is Iran an Islamic State?', in Joel Beinin and Joe Stork (eds), Political Islam: Essays from Middle East Report (Berkeley: University of California Press, 1997), p. 104. Sami Zubaida has argued as much for the case of post-revolution Iran, and the same holds true for the Negara Islam Indonesia. 
In a socialist vein, the Qanun sanctioned the right for all citizens to work and to maintain appropriate standards of living. It also established the principle of mutual aid for matters pertaining to the life and livelihood of the people, and the right-duty to pursue an education, which would be facilitated by the government's establishment of a system of Islamic schooling. The state would control 'the branches of production of major importance to the nation and its people', as well as soil, water and natural resources in order to ensure maximum benefit for the people.

\section{Reaching out: Promoting the common goal}

With the TNI officially evacuated from West Java, the Islamic Army supplied the only organized anti-Dutch troops. Although they were not the only 'irregulars' operating in the province, the NII was establishing itself as a regional political institution with links to the centre, whilst the various laskar did not have a central leadership. In October 1948 the Dutch Army labelled Kasman Singodimedjo, Sangadji and Anwar Tjokroaminoto as the Jakarta supporters of the Tasikmalayabased Darul Islam, ${ }^{55}$ and in December of that year Kartosuwiryo himself announced that Abikoesno and Anwar Tjokroaminoto were 'representatives of the NII in the Republican territories'. ${ }^{56}$

As the DI-TII affirmed its position in the Priangan as a military and civilian institution, Kartosuwiryo and his aides saw an opportunity to reach out to the Republican government to ask for recognition of their successes against the Dutch and for support in continuing the struggle.

On 3 October 1948, K.H. Zainal Hasan Thoha (political chief of MOI in Ciamis) and Nur Lubis (the Batak commander of TII's 3rd Battalion in Tasikmalaya and Ciamis) sent letters to Muhammad Natsir (at that time Minister of Information), the chief of the Republican delegation in Yogyakarta, Mohammad Roem, and the vice-president, Mohammad Hatta. ${ }^{57}$ These three letters appealed for material help - namely, weapons - from the Republic, expressing the 'hope' that the Republic would be interested in West Java's struggle against the occupying forces.

\footnotetext{
55 'Beknopt Politiek-Politioneel Verslag der vreemdelingen- en inlichtingen Dienst (VID), no. 10/1948', APG no. 1068, NA.

56 'Maklumat Negara Islam Indonesia no. 6', 20 Safar 1368 AH/21 December 1948 CE, in Al Chaidar, Pemikiran politik, pp. 556-7.

57 The last two letters were said to be copies of ones previously sent, which had gone unanswered and were thus deemed not to have been received.
} 
Each letter tackled the issue in a way that was tailored to the character and position of the recipient. The letter to Roem was a direct and bare-boned request for moral, political and material support, sweetened by the hopes of this Islamic State's commanders that Roem would not let the rebellion go unknown in Republican circles. ${ }^{58}$ The other two letters, on the other hand, went to great lengths to explain why a guerrilla movement had been organized on Mount Cupu, with Natsir even addressed as an ally:

As a Muslim, surely you must be happy about this rebellious Muslim movement in West Java, and that the great strength that you have often mentioned as being with the Muslim group is indeed real. Unfortunately, this government, led by a leftist coalition, does not care about it, and its strength cannot be used to stop the Dutch aggression. This rebellion in West Java shows that Muslims truly love independence. With a few rifles and firm faith, the rebellion started on Mount Cupu on 17 February [1948]..$^{59}$

Hatta's letter presented him with the matter-of-fact statement that 'the future of the occupied areas lies $99 \%$ with the result of this rebellion', and that the only reason for Yogyakarta's independence was TII's activity in West Java. The Darul Islam had no naive expectations of receiving any substantial material help from the Republic. But it used this opportunity to remind the Republican leadership that it should not forget that many Indonesians were still under foreign rule, in part because of the decisions made by the Yogyakarta government, and that, as the Siliwangi Division had taken the 'good and heavy weapons' into Republican areas, the Darul Islam could not guarantee a quick victory in West Java. ${ }^{60}$ Their requests went unheeded.

On 19 December 1948 the Dutch Army invaded Central Java, entered Yogyakarta and captured the president, the vice-president,

58 Letter to P.T. Mr. Muhammad Rum Ketua Delegasi Republik Indonesia di Yogyakarta from Pimpinan Ummat Islam Kabupaten Tjiamis KH Zainal Hasan Thoha and Tentara Islam Indonesia Bat. III Res. I Div. I Komandan Bat. III Muhammad Nur Lubis, 3 October 1948, JogjaDoc no. 150 , ANRI.

59 Letter to J.M. Muhammad Natsir Menteri Penerangan Republik Indonesia di Yogyakarta from Pimpinan Ummat Islam Kabupaten Tjiamis KH Zainal Hasan Thoha and Tentara Islam Indonesia Bat. III Res. I Div. I Komandan Bat. III Muhammad Nur Lubis, 3 October 1948, JogjaDoc no. 150, ANRI.

60 Letter to P.J.M. Wkl. Presiden Republik Indonesia Drs. Mohammad Hatta di Yogyakarta from Pimpinan Ummat Islam Kabupaten Tjiamis KH Zainal Hasan Thoha and Tentara Islam Indonesia Bat. III Res. I Div. I Komandan Bat. III Muhammad Nur Lubis, 3 October 1948, JogjaDoc no. 150, ANRI. Quote also from this letter. 
the head of KNIP and the Minister of Foreign Affairs. ${ }^{61}$ This was a serious setback to the creation of an independent state of Indonesia, and it also greatly contributed to the shaping of Darul IslamRepublik Indonesia relations.

GROWING APART (DECEMBER 1948-AUGUST 1949)

Against the backdrop of these kidnappings and the collapse of the Republican government, in late December Kartosuwiryo declared a 'holy war, total war, all-encompassing people's war, against the Netherlands' to ensure the success of the Islamic revolution and the establishment of a perfect Islamic state across Indonesia. ${ }^{62}$ The Dutch intervention gave Kartosuwiryo another opportunity to accuse the Republican government of its political failings, and at the same time to glorify the Islamic state as the only viable option for independent Indonesia.

In the following months Republican leaders conducted intense diplomatic talks with the Dutch, whilst the Siliwangi Division returned to West Java. Until mid 1949, relations between Republican agents and the DI-TII could best be characterized as an uneasy collaboration marked by the consciousness that, despite territorial divisions, resisting Dutch expansion should be their common goal.

\section{Tentara Islam Indonesia and the Siliwangi in West Java: an uneasy cohabitation (December 1948-February 1949)}

The Dutch operations prompted a new round of diplomatic negotiations, in which the Republican bargaining power was further weakened. Kartosuwiryo's response to the situation was clear:

It will not be long before they sign a new treaty - this is the story of the Indonesian independence struggle - and this third treaty will decide the fate of the State of the Indonesian Republic. In our understanding, at that point the Republic won't be anything more than a 'Puppet State' like those the Dutch have already established a while ago: Negara Indonesia Timur, 'Negara' Kalimantan, 'Negara' Pasoendan, and so forth. Thus, with the use of weapons,

61 Ricklefs, A history, p. 230.

62 'Maklumat Negara Islam Indonesia no. 5', 19 Safar 1368 AH/20 December 1948 CE, AABRI DI [folii]. 
the Netherlands will force the Republican government, which has already been captured, to sign a treaty according to which all the state's instruments will have to be abandoned [here anticipating the Roem-Van Royen statement of May 1949 ... ]. Because of this, there is nothing for the Indonesian Islamic community, especially those living in Republican territory, to do other than to be ready to accept God's gift, to pursue a jihad fi Sabilillah, to oppose the enemy of Islam, the enemy of the State, and the enemy of God, and last but not least, to establish a State blessed and offered by God, an Islamic State of Indonesia. ${ }^{63}$

Kartosuwiryo's disappointment with the Republican government is evident. However, it would be a mistake to argue that the Darul Islam maintained an 'openly anti-Republican' attitude, as Kahin and Boland have suggested. ${ }^{64}$

On 21 December 1948 Kartosuwiryo declared that the struggle for the Islamic state was 'the continuation of the independence struggle, following on from and in line with the 17 August 1945 proclamation'. In this statement, Kartosuwiryo was placing the Darul Islam's struggle on the same plane as Soekarno's, rather than in opposition to it. ${ }^{65}$ Two days later he renewed the Islamic state's 'state of war', specifying that it involved only two contenders: the NII and the Dutch government. Between the two neither cooperation nor treaties were allowed, and ongoing diplomatic contact had to be ceased ${ }^{66}$ Kartosuwiryo was thus pledging to continue Soekarno's struggle whilst he and his cabinet had been captured, and Republican forces were not identified as the enemy.

Following the Dutch offensive of December 1948, the Siliwangi Division crossed the Van Mook line, re-entering West Java and reigniting tensions between regular soldiers and Islamic militias, tensions about which Colonel Nasution was well aware.

63 'Maklumat Negara Islam Indonesia no. 6', 20 Safar 1368 AH/21 December 1948 CE in Al Chaidar, Pemikiran politik, pp. 556-7. Here Kartosuwiryo anticipated the Roem-Van Royen statement, which was signed on 7 May 1949. Regulating the transfer of sovereignty, this agreement had been heavily pushed for by the international community, as had the Renville Agreement. The international community had begun to tire of Dutch policies in the archipelago. An interesting account of these events, and of the reactions of the international community, is offered by TIME Magazine; see 'Regretfully obliged', 27 December 1948; 'So moves the world', 3 January 1949; 'Merdeka!', 10 January 1949; 'What about the baby?', 10 January 1949.

64 Kahin, Nationalism and revolution, p. 330; Boland, The struggle of Islam, p. 58.

65 'Maklumat Negara Islam Indonesia no. 6', 20 Safar 1368 AH/21 December 1948 CE, in Al Chaidar, Pemikiran politik, pp. 556-7.

66 'Maklumat Negara Islam Indonesia no. 7', 22 Safar 1368 AH/23 December 1948 CE, in Al Chaidar, Pemikiran politik, pp. 558-9. 
The return of the Siliwangi Division to West Java stirred much commotion in DI-TII circles. In late January 1949, a new NII decree blamed Republican troops for abandoning the region and returning one year later, not as 'guests' of the Islamic state, but rather as rulers who expected to take charge of NII territory. The TNI was aware that the NII considered the return of the Siliwangi troops a breach of NII's sovereignty, ${ }^{67}$ and saw its soldiers as a tentara liar (wild, illegal militia), an 'obstacle' to the Islamic revolution and an enemy of the Islamic state. ${ }^{68}$ The 25 th of January - the day of this decree - is also considered by the Republican Army as the day when 'the TNI betrayed the Tentara Islam Indonesia'. The aggression of the TNI on that day was taken as a sign of enmity towards the Tentara Islam Indonesia and the Islamic ummah. ${ }^{69}$

Even though January and February 1949 witnessed attacks on several TNI battalions by Islamic soldiers around Tasikmalaya, Ciamis, Kuningan and Majalengka, clear rules of engagement prohibited the Islamic Army from killing Republican troops, who were only to be relieved of their equipment and then dispersed. ${ }^{70}$

Nevertheless, cases of cooperation continued to be reported. For example, TNI and TII troops stationed in Parigi, in the South Priangan, resolved to cooperate to ensure that all soldiers had food and weapons - the people's predilection for Islamic militias remained a key element in ensuring their livelihood. ${ }^{71}$ The beginning of the year saw cooperation in the Kuningan and Jakarta areas as well, to the extent that in Jakarta this cooperation gave rise to worries in the office of the Dutch Indies' attorney general, which had received documentation proving that the Sjarif Hidajatullah Division of TII in Central Java had obtained ammunitions and weapons from the commander of the regional police. $^{72}$

67 'Maklumat no. 10 Siliwangi Djawa Barat', 10 April 1949, AABRI DI no. 4. Kedatangan Tentara kita dianggap sebagai melanggar kedaulatan negara tsb [NII] berhubung memang Tentara kita bertugas untuk membangun kembali Pemerintah republik di Jawa Barat.

68 'Maklumat Negara Islam Indonesia Militer no. 1', 25 January 1949, in Al Chaidar, Pemikiran politik, pp. 652-4.

69 'Tanggal2 bersedjarah bagi Gerombolan D.I.' [1952?], AABRI DI no. 14. TNI melakukan penghianatan kepada Tentara Islam Indonesia.

70 'Maklumat Negara Islam Indonesia Militer no. 1', 25 January 1949, in Al Chaidar, Pemikiran politik, pp. 652-4.

71 'Beknopt Politiek-Politioneel Verslag van de regentschappen Bandoeng, Garoet, Tasikmalaja, Tjiamis, Soemedang, Cheribon, Koeningan, Indramajoe, Madjalengka, Poerwakarta, Soekaboemi, Tjiandjoer en Buitenzorg, over de maand Februari 1949', AMK:RI no. 285, NA

72 'Aanbieding documenten betreffende TII- en TNI-aangelegenheden', 21 September 1949, APG no. 907, NA. 
But from April 1949 onwards, the TNI reportedly joined forces with the Dutch in an attempt to clear Darul Islam pockets in West Java. ${ }^{73}$ What changed the relationship so swiftly and so dramatically?

\section{... and an easy divorce (February-March 1949)}

On 26 February 1949 Kartosuwiryo and Oni held a conference in Langkaplancar (in the South Priangan), during which they presented the TNI with an ultimatum: the TNI could either leave the region or join the ranks of the Darul Islam, but beginning in April the only army allowed to operate in the region would be the Tentara Islam Indonesia. ${ }^{74}$

As the Republic readied itself for yet another round of negotiations, the Darul Islam began preparations to expand its territorial reach. In mid April, it sent a 'consul' for the NII to Sumatra with the intention of leading the local $\mathrm{ummah}^{75}$ According to a Dutch intelligence report, it is at this same time that a Javanese associate of Kartosuwiryo developed cells in the Palembang, Bengkulu, Lampung, Jambi and Tapanuli areas as well as on the west coast, and that the first contacts between Kartosuwiryo and Daud Beureueh in Aceh took place. Beureueh was a former leader of the Persatuan Ulama Seluruh Aceh (PUSA, All-Aceh Union of Ulamas) and in July 1947 he had been nominated military governor of Aceh. The Dutch also detected Darul Islam groups in South Borneo, the Moluccas and Sumbawa, and a small enclave was active in the Lesser Sunda Islands. ${ }^{76}$ There is also evidence that Kahar Mudzakkar posed as panglima (commander) of the IV DI Province of Eastern Indonesia soon after the proclamation of the NII, whilst it is generally accepted that he joined the Darul Islam in early $1952 .{ }^{77}$

After the ultimatum, and probably as a way to justify such a dramatic change in attitude, in March 1949 Kartosuwiryo published a pamphlet on the history of the ummah's struggle for independence and the secularists' track-record in diplomatic negotiations. In adDaulatul Islamiyah Kartosuwiryo drew attention to the nationalists'

\footnotetext{
73 'Beknopt Politiek-Politioneel Verslag over de maand April 1949 van de regentschappen in de Negara', AMK:RI no. 285, NA.

74 'Beknopt Politiek-Politioneel Verslag over de maand Maart 1949 van de regentschappen in de Negara Pasundan', AMK:RI no. 285, NA.

75 'Tanggal2 bersedjarah bagi Gerombolan D.I.' [1952?], AABRI DI no. 14.

76 'CMI Signalement de Negara Islam Indonesia', 21 October 1949, AAS no. 3979, NA.

77 See, for example, Van Dijk, Rebellion under the banner of Islam, p. 187. 'Perkembangan D.I. Djawa Barat S.M. Kartosuwiryo', AABRI DI [folii].
} 
cooperative attitude - first towards the Dutch, then towards the Japanese, and, finally, towards the Dutch once again. ${ }^{78}$

To Kartosuwiryo, Soekarno's readiness to bargain with the Dutch had made a 'zoo' (kebon binatang) of the early independence movement: as the animals, the politicians could 'freely' move around, but they were limited by the cages and guards of the colonial administrators. Once Japan replaced the Netherlands, the zoo became a circus (komidi kuda), with each animal playing its part in the well-orchestrated farce of independence, tragically ended by the atomic bombings. As he himself was one of the animals in this Japanese circus, Kartosuwiryo may have felt betrayed when Japan, after having co-opted the Islamic movement in order to garner popular support, eventually entrusted the task of drafting the constitution to the secular nationalists.

Kartosuwiryo accused Sjahrir of selling out Indonesia's independence at Linggadjati, and Sjarifuddin, of leading the Republican boat through shallow waters until it ran aground on West Java in the aftermath of Renville (Bahtera Republik terdampar). Kartosuwiryo did not place all the blame on the Republican leaders, though, as he recognized they had been lured by the deceptions of the international community, which was interested in stalling the revolution. They had been victims of an illness that no dukun healer could cure - diplomacy.

When the anti-colonial Islamic revolution was spreading from Mount Cupu into the western part of Java, too many had preferred to play it safe by fleeing across the Van Mook line, working for the Dutch government in West Java, waiting passively for things to change, or seeking help from Yogyakarta. Yet, Kartosuwiryo concluded, all Soekarno and Hatta could deliver to the people were empty hopes, a second military campaign and the inevitable failure of the Yogyakarta Republic as an independent government.

\section{Opposing reactions: Clashing military and political interests (April-August 1949)}

During April, military commanders' concerns over the number of TNI soldiers that were falling victim to the Darul Islam were opposed by Masyumi and other political organizations who were instead concerned by the ruthlessness of the army's response and the future of political Islam in general. 
Awareness of the Darul Islam's position on the Siliwangi Division's 'intrusion' in West Java had not stopped Commander in Chief Colonel Nasution from affirming that his duty was 'to reestablish the Republican government' in the region. ${ }^{79}$ Reporting from the Priangan, he complained that the Siliwangi Division was 'squeezed' between Dutch and Islamic troops and was suffering heavy losses.

According to Colonel Nasution, by April almost one thousand Siliwangi soldiers had been captured by the Darul Islam. Even after the local ceasefire, signed on 12 April 1949, dozens of TNI soldiers came under Darul Islam fire. In response, the division interrupted the Cirebon-Tasikmalaya road, killed a dozen Darul Islam men, burned down a factory, disturbed Darul Islam meetings in Kuningan and Ciamis, increased patrolling, hijacked two trucks and seized eighteen rifles. The following month, after being informed of Major Sentot's success in cleansing the Cirebon area, Nasution admitted that his repeated attempts to negotiate and cooperate with the Darul Islam had failed, as had those conducted by Colonel Sadikin in Tasikmalaya. A plan to eradicate the militia was now needed. Major Hardjono, in mid May, stated that the Darul Islam's unwillingness to cooperate was forcing his troops to begin purging the area. ${ }^{80}$

In the wake of the Roem-Van Royen Agreement, relations between the Darul Islam and the Republic had worsened. From May 1949 the ambiguities in their positions dissipated, and their differences came into sharper relief. In principle, the Islamic state was not opposed to the Republican government in Yogyakarta, but in practice it opposed Dutch interference in Indonesian politics and Dutch authority over Indonesian territory. The Darul Islam argued that West Java, as part of the occupied territories, did not fall under the control of the Yogyakarta Republic, and thus should not be forced to abide by the treaty signed by Republican leaders. In fighting the Siliwangi troops, the Darul Islam did not see itself as attacking Soekarno's Republic but, rather, as attacking the Dutch government, which was making use of Republican troops to advance its own agenda. The Indonesian Republic had become a 'puppet' in the hands of the Dutch, and was thus standing behind

79 'Maklumat no. 10 Siliwangi Djawa Barat', 10 April 1949, AABRI DI no. 4.

80 Col. A.H. Nasution on West Java and DI/TNI clashes, doc. no. 0211/pl oi/25, 26 April 1949, Pemerintah Darurat RI, 1949 [hereafter PDRI] no. 91a, ANRI; 'Darul Islam contra TNI te Tasikmalaja', Territoriaal Troepencommando East Java, 3 Mei 1949, MD:AS no. 2071, NA; Major Harjono on 'Pembersihan terhadap DI', 19 May 1949, PDRI no. 92, ANRI; 'Laporan HBKD PTTS', 23 June 1949, PDRI no. 151, ANRI. 
enemy lines. Although this change in perspective had become evident to military commanders and politicians alike, Masyumi did not approve of Colonel Nasution's hard line, and party leaders pleaded with him not to attack Islamic troops and not even to enter the areas they controlled.

Regardless of the fact that the Darul Islam had no institutional link to Masyumi, the party went all out to defend the Islamic Army. They vigorously argued that the clashes with the TNI were partly in response to attacks on the part of the Siliwangi Division - attacks that had been ordered by Achmad Wiranatakoesoema and which were frowned upon by other TNI commanders - and partly a consequence of bandits roaming the border between Central and West Java, which made it difficult to establish who was TNI and who was not.

On the political front, Masyumi maintained that TNI's attacks on the Darul Islam were strengthening the Dutch scheme of 'divide and rule' and weakening popular support for the Republic across the country, and not just in those areas directly controlled by the Darul Islam. Masyumi leadership was sure that once the Dutch had left, the situation would be easily resolved by removing the source of discontent in West Java. ${ }^{81}$

Despite pleas for unity from Lieutenant Colonel Sudirman, who called for groups from all ideological paths to join in a holy struggle of total war (perjuangan suci, though not a perang suci), ${ }^{82}$ and despite Masyumi's repeated attempts to mediate between the Siliwangi Division and the Darul Islam, ${ }^{83}$ press and military reports show that by late July, and even more so from August 1949, negotiations and discussions regarding cooperation had failed. This failure was the result, on the one hand, of the Darul Islam's resentment of the Yogyakarta Republic, and on the other hand, of the TNI army's suspicion that after the communist militias had been crushed in Central and East Java in late 1948, they had heavily infiltrated the Islamic Army, especially in the Cirebon area. $^{84}$

81 Letter from Prawoto Mangkusasmito, Pengurus Besar Masyumi, to Panglima Komando Jawa on 'Darul Islam', 9 April 1949, Kabinet Perdana Menteri RI, Yogyakarta, 1949-1950 [hereafter KabPerd] no. 150, ANRI; Letter from Muhamad Saleh, Pengurus Besar Masyumi, to Panglima Komando Jawa on 'Darul Islam', 7 May 1949, KabPerd no. 150, ANRI.

82 Letter from Panglima Komando Jawa, Lieutenant Colonel Sudirman, 9 May 1949, AABRI DI no. 4.

83 'Masjumi bemiddelaar tussen de Siliwangi en de Darul Islam?', Indonesisch pers en radio overzicht, Java, 12 August 1949.

84 'Communistische infiltratie in de Darul Islam', Nieuwe Courant, 22 June 1949. For more details on DI and communism, see Chapter 6. 
DECLARING AN ISLAMIC STATE IN 'OCCUPIED' WEST JAVA (AUGUST 1949)

The Negara Islam Indonesia was rooted in the law of God and had its base in 'Medina'. As had been anticipated in the Brosoer sikap hidjrah PSII and in Haloean politik Islam, this choice of toponym pointed to the city's status as the destination of the hijrah, as a physical migration and a metaphoric transformation. Either way, Kartosuwiryo referred to the beginning of a new life for the ummah, one in full conformity with Islam. The NII extended across five regencies in West and Central Java: the Priangan (in Bandung, Garut, Tasikmalaya, Ciamis,and Sumedang districts), Cirebon (Cirebon city, Indramayu and Majalengka), Pekalongan (Brebes and Tegal), Banyumas and Bogor.

The NII had existed, de facto, since August 1948, when the first 'announcement' (or decree) bearing its name appeared. But the Islamic State proclamation of August 1949 represents the important transformation from a nebulously defined, idealized project to a meticulously detailed state with a blueprint for executive, legislative and judicial government institutions.

The former Masyumi branch of West Java had finally achieved the goal that the central party had set in 1945: the establishment of a republic that was based on Islam, implemented Islamic laws and directly controlled its territory. Success had only become possible in August 1949 after the 'betrayals' of the Republican government and the ummah's many disappointments.

The circumstances that had enabled Kartosuwiryo and his partners to proclaim the NII were clearly explained in a political manifesto released a few weeks after the NII proclamation. In Kartosuwiryo's eyes, this text was a direct result of the Roem-Van Royen statement, which had epitomized diplomatic relations between the Netherlands and the Indonesian Republic: the ceasefire, the Round Table Conference and sustained cooperation between the two parties. Kartosuwiryo's objection to each and every point was grounded in political and historical considerations. He characterized Soekarno's authority as that of a slave who had been turned into a king by the Devil, and his political strategy as weak, disillusioned and outdated. He believed Soekarno to only be capable of selling out his country to the foreign occupier.

Kartosuwiryo pointed out that Soekarno had risen to represent the entire archipelago, even though no other leader had delegated his decisional powers to the Republican cabinet. But when bullied by the Dutch, Soekarno could do nothing more than surrender 
Indonesia's sovereignty to them. The Federal Republic of Indonesia (RIS) was built on 'fake' authority, as it was a 'gift' from the colonial government and it still carried the shadow of Dutch control and supervision. Kartosuwiryo saw this dynamic as little more than a modern form of colonialism in the context of which Indonesia would only have been half-independent, as a dominion or a protectorate.

Kartosuwiryo's rejection of anything short of de facto and de jure independence was reinforced by his open condemnation of Pakistan's status as a British dominion. Soekarno's debacle had caused the end of the Republican cabinet and the collapse of the ummah, but Kartosuwiryo saw these events as 'a gift from God' that had empowered the Darul Islam to proclaim the Islamic state..$^{85}$

The May ceasefire agreement was set to end hostilities on 1 August 1949. However, in Java, a fortnight passed before any real progress in ending the conflict was made. The Siliwangi Division pledged to obey the ceasefire and held meetings with local laskar to facilitate the transfer of authority and the troops' incorporation into the Republican Army. ${ }^{86}$ Although the Antara news service reported that TII and TNI troops around Ciamis had initially agreed to abide by the ceasefire and would 'cooperate in wiping out irresponsible elements', ${ }^{87}$ this solution was not embraced by every Darul Islam cell, as in the last weeks of August its militias continued to attack the Dutch, the TNI and, reportedly, also the civilian population in the Cirebon area and west of Jakarta. ${ }^{88}$ It was in this charged political environment that Hatta left Jakarta to attend the Round Table Conference in The Hague, lasting until November 1949.

\section{The Proclamation of the Negara Islam Indonesia}

In part a result of Soekarno's weakness, the Indonesian Republic was visibly crumbling under pressure from international diplomatic efforts. The Negara Islam Indonesia was officially declared against this backdrop on 7 August 1949, during the 20th session of the dewan imamah in Cimampang, a meeting held in the aftermath of the Roem-Van Royen Agreement and attended by Kartosuwiryo, K.H. Gozali Toesi, Sanoesi Partawidjaja, Oni and Toha Arsjad. 
Pragmatic and detailed as it was, this proclamation was still a theoretical statement that together with the 1948 Constitution presented an alternative to Soekarno's 1945 text. In Kartosuwiryo's vision the NII would evolve from a core 'Negara Basis', named Madinah Indonesia, with only de facto authority over a small portion of Indonesia, into a 'Negara Kurnia Allah' - a fully sovereign state. Solidifying the state into a permanent entity could only be obtained through a dramatic shift in the balance of power: locally, Kartosuwiryo called for an Islamic revolution; internationally, for a Third World War or a World Revolution 'more devastating and violent than the previous ones so that, God willing, the international situation will deeply change'.

Aware of the movement's current limitations, the dewan imamah stated that the daulatul Islamiya, or Darul Islam, would continue to conduct a holy war until it was transformed in the envisaged 'Negara Basis'? the NII would include the entire territory of the archipelago, be recognised as a de facto and de jure state, it would implement Islamic law, abolish slavery, and ensure that all enemies of Allah, religion and the state had left. Until these goals were met, the NII would be in a state of war (Negara Islam dimasa perang or dar-ul-Islam fi-waqtil-harbi), ruled by Islamic martial law. The time was ripe for establishing 'God's justice in this world', and Kartosuwiryo called upon the Indonesian ummah to pursue 'the holy duty of guarding the integrity of the NII' ${ }^{89}$

\section{The NII's criminal code}

With Kartosuwiryo's formal proclamation of the NII as a political and administrative entity, what had so far been a theoretical proposal had now become a functioning state. The commitment to territorial expansion across the archipelago was supported by the efforts to provide this state with a strong legal infrastructure, including a criminal code, the Hukum pidana. This text dedicated considerable attention to killings, banditry and martial law, reflecting the current state of war in which the NII found itself. The code arranged the material in a semi-systematic presentation of qisas (retribution in equal measure), diya (compensation money), ta'zir (discretional punishment) and hudud (crimes and punishments mentioned in the Qur'an), following the classic fiqhi distinction between crimes and punishments. Here I address only the code's martial law, as its remainder is analysed in Chap- 
ter 6 in comparison with the codes issues by the Majelis Mujahidin Indonesia (Indonesian Council of Mujahidin, MMI) in 2002 and 2005.

The NII code dedicated several articles to Islamic martial law. Its first article reiterated the fact that the 'Indonesian State' ( $\mathrm{Neg}$ ara Indonesia) was an Islamic state currently at war and therefore subject to hukum syariat Islam dalam masa perang. This held four fundamental obligations, with their respective punishments. Whoever did not follow the instructions of the Islamic state, including those who did not surrender financial surplus to the treasury as contribution towards jihad, was to be considered a bughat (rebel) and punished by banishment or death (quoting Qur'an 4:58), but only if he did not rectify the situation after being taken into custody and admonished. Death was directly prescribed for the three remaining categories of offenders: hypocrites, sinners and enemies of the state. Munafiq (hypocrite) was the one who maintained good relations with the state's enemies, despite having been informed by the government of such prohibition (quoting Q 60:1; 9:73; 66:9). Fasik (sinner) was the Muslim who did not follow Islamic law; if he refused to repent, he was to be labelled an enemy of Islam and punished accordingly. Enemies of the state were all those who had 'become tools of the colonial power' in civil, military and auxiliary circumstances, unless these actions were pursued in fulfilment of orders from the Islamic government. Punishment was of two kinds: he who assisted the colonial government without bringing any disadvantage to the Islamic state was to stop all activities; but he who spied for the enemy, thus bringing direct harm to the Islamic state, was to be sentenced to death (quoting $\mathrm{Q}$ 4:89).

Adherence to martial law-described as one of the five pillars of jihad - was a fard al-'ayn except for the blind, crippled, sick, physically weak and those affected by infectious diseases (quoting $\mathrm{Q}$ 9:90).$^{90}$ All the free, sane and physically able adult Muslim males had the duty to participate in jihad against those who waged war on the state (defined as orang muharib and kafir harbi, infidels of war), and those who, after appropriate investigation, appeared to be supporting the enemy. It was the imam or amir's decision whether these enemies were to be executed, exchanged for captives of war or seized goods, enslaved or, even, set free.

90 This same article is referred to in Pinardi, Sekarmadji Maridjan, as Q 9:91. In Pinardi, the second group exempted from participating in jihad is said to be rincang, explained as sakit mata (those with eye defects); however, rincang does not appear to exist in Indonesian, and it is likely to be a misreading of pintjang (the crippled). 
According to the text, in times of war there were only two communities: the ummat Negara Islam (ummah Muslimin), and the infidel oppressor (ummat penjajah, colonizer; ummat kafirin, infidel). Enemies are defined as those who do not adhere to Islam, those who do not recognize as forbidden what Allah forbade, those who had broken their pledge of loyalty (muharrib), polytheists (mushrik), the munafiq (quoting $\mathrm{Q}$ 8:38; 9:12, 28, 72; 4:75), bughat and bandits. In addition to the more general understanding of bughat as someone who broke the rules of the state, this term has also acquired a very politicized connotation since the Battle of Siffin, when it was used to describe those who did not recognize the authority of the imam. Here the term was used for the person who refused to follow the imam as leader of the state, even though the community had agreed upon his nomination. Martial law allowed the arrests of those who disseminated non-Islamic propaganda, those who in so doing disturbed the peace and order of the state, those who unsettled the population, those who contributed to strengthening the enemy, and those who were suspected of being a danger to the Islamic state (quoting S. Anas, hadith n. 7, Subulussalam, Muhadhanah).

During times of peace these same crimes were punished with imprisonment or ta'zir. The same article also offered guidance for handling the bughat, who was to be arrested and lectured on Islam for the first offence and, if arrested again, sentenced to banishment or capital execution; the fasik was first to be advised against strengthening the enemy, and only when this had failed was he to be punished with the impounding of his wealth. Only enemies who harboured the intention of opposing the state and who planned to weaken Islam politically, or tactically, could be held in captivity.

Whilst those arrested (ditangkap) were to be judged by a court, those held captive (ditawan) were considered spoils of war and had their punishments decided by the imam or amir, whether these captives were infidel sane men, women, children, mentally insane or transvestites $\left(\right.$ wand $\left.u^{91}\right)$. The spoils also included: (a) goods belonging to the enemy and left behind; (b) goods seized from polytheists; (c) tenants of state land; (d) goods belonging to executed apostates; (e) goods belonging to a kafir aman (non-Muslim who had been granted safety) with no heirs; and (f) the commercial value of infidels who traded in the country. All these goods were to be considered $f a^{\prime} i$ (goods obtained from the enemy, but not in battle), and to be included in the Mushalihu'l-Muslimin community fund.

91 Pinardi uses banci, an alternative, yet more derogatory, term. 
The spoils acquired in battle (ghanimah) were to be shared between the state treasury (which received $80 \%$ of the total) and - in equal parts - among the imam, the poor, the orphans, those who had participated in the battle (Ibnu'sabil), and the community fund administered by the imam (each receiving $4 \%$ of the remaining $20 \%$ ). Still following Shafi'i doctrine, $80 \%$ of $f a{ }^{\prime} i$ was given to the Islamic state, and the rest was divided in the same fashion as the ghanimah. Salab (what the enemy had used in battle) was instead taken in full by those who had participated in the military action. The captives of war could be either non-Muslims (kafir) or apostates (murtad): kafir were condemned to become slaves and property of the state, and decisions about their future were made by the imam and his representatives; murtad had the chance to repent of the misdeed of not following the laws of the Islamic state. Failing to do so within three days meant that they were to be sentenced to death. A person could only marry a captive female murtad once she had observed the ' $i d d a$ waiting period of three months and ten days, which only began when approved by the imam or his representative, the judge.

\section{INITIAL ATTEMPTS TO RECONCILIATION (AUGUST-OCTOBER 1949)}

The Republic was committed to negotiating a compromise with the Darul Islam. During a time when clashes were still occurring, Hatta sent Muhammad Natsir to Bandung to make contact with Kartosuwiryo. Natsir had originally refused to admit that he was trying to negotiate with the Darul Islam; however, once he arrived in Bandung, Natsir decided to involve their educator and friend Ahmad Hassan of Persis, hoping that Kartosuwiryo would respect their common teacher enough to agree to a meeting and even a compromise.$^{92}$ Confronted by Ahmad Hassan, who carried a letter written by Natsir, on 10 August 1949 Kartosuwiryo explained that the Islamic state had already been proclaimed three days earlier, and that he could not undo this act. Natsir also recalls that Kartosuwiryo complained to Ahmad Hassan that the request was not 'official enough' to be taken into consideration, as it had been written on letter-headed stationary. ${ }^{93}$ As negotiations had come to nothing,

92 Antara News on 1 September 1949 reported: 'When questioned about the truth of newspapers' reports that he had contacted the irregular troops of DI [Natsir said]: is it possible that within two nights can I have contacted the DI whose headquarters are not even in Bandung?' 93 Panitya Buku Peringatan Muhammad Natsir, Muhammad Natsir 70 tahun kenang-kenangan kehidupan dan perjuangan, (Jakarta: Pustaka Antara, 1978), pp. 185-6. 
the Darul Islam established itself in the rural areas whilst the TNI maintained its hold on the cities. ${ }^{94}$

As the Priangan was a firmly consolidated Darul Islam area, the struggle was now mostly conducted on the north coast in the Cirebon regency. Here, in the surroundings of Tegal and Brebes, the former TNI colonel and then commander of the TII Sjarif Hidajatullah division, Amir Fatah, led groups of 200-500 men, circulated NII pamphlets and regularly engaged with the TNI. ${ }^{95}$ The clashes continued ${ }^{96}$ even after the Darul Islam agreed, in early September 1949 , to lay down its weapons and be incorporated into the Republican Army, provided that all TNI units located in Cirebon and the East Priangan were replaced with new troops who had not previously fought against the Islamic Army. ${ }^{97}$ By the end of the first week of September, Darul Islam troops had withdrawn from West Cirebon, but the 'Darul Islam problem' was far from solved. ${ }^{98}$

In September, the Dutch-language newspaper Nieuwe Courant called the NII proclamation 'a coup d'état in the Pasoendan', and the Semarang-based Sulu Rakjat condemned the Darul Islam movement for "having nothing to do with the actual meaning of its name, "house of peace"'. Even so, Masyumi leaders Muhammad Natsir and Zainal Arifin, as well as TNI Colonel Sadikin, decided to take some conciliatory steps. ${ }^{99}$

Steering clear of either condemning or praising the Darul Islam, Natsir encouraged Indonesians to see the difference between those who really wanted to advance the Islamic state ideal and those who instead only sought excuses to perpetrate vandalism. He went further, holding the Dutch responsible for creating the conditions

94 'Het cease fire bevel wordt over het algemeen gehoorzaamd', in Indonesisch pers en radio overzicht, Java, 25 August 1949. It is worth noting that despite the fact that rural and urban areas came under different spheres of control, the press noticed that the flow of daily supplies to the civilian population was not interrupted.

95 'Daroel Islam verdrijft TNI uit desa's', De Vrije Pers, 27 August 1949; 'CMI Signalement de Negara Islam Indonesia', 21 October 1949, AAS no. 3979, NA.

96 'Terreur door de Daroel Islam', De Vrije Pers, 2 September 1949; 'Strijd tussen Darul Islam en TNI', Nieuwe Courant, 5 September 1949; 'Gevechten tussen TNI en Daroel Islam', Vrije Pers, 5 September 1949; 'Strijd Tussen TNI en DI', De Vrije Pers, 10 September 1949; 'Darul Islam bertempur', Berita, 8 November 1949; 'Daroel Islam merampok', Sin Po, 9 November 1949; 'D.I. terreur neemt steeds ernstiger vormen aan', De Vrije Pers, 12 November 1949; 'DI menjerbu', Merdeka, 17 November 1949; 'Sekitar activiteit Daroel Islam', Java Post, 15 November 1949; 'Weer een bloedbad van Darul Islam-benden', De Vrije Pers, 18 November 1949.

97 'De "Darul Islam" bereid de wapens neer te leggen en tot de TNI toe te treden', A.P.B., 1 September 1949; 'Darul Islam masuk TNI', Berita, 3 September 1949. It is likely that these articles referred to local groups carrying the name 'Darul Islam', rather than the regional movement.

98 'De situatie in Banjumas en in het Indramajuse', A.P.B., 6 September 1949.

99 'Darul Islam', Suluh Rakjat, in Indonesisch pers en radio overzicht, Java, 9 September 1949; 'Bij Daroel Islam heet alles: straf-maatregel in oorlogstijd', Nieuwe Courant, 8 September 1949. 
that led to the emergence of an Islamic movement in the Priangan when they first invaded Java in July 1947, and accusing them of now conducting a 'systematic media campaign' against it. ${ }^{100}$

By mid September, Natsir was chairing a commission for the study of the Darul Islam, which soon concluded that the Republic should not destroy Kartosuwiryo's movement. ${ }^{101}$ Sadikin, now commander of the Siliwangi Division, stated that the TNI would not eliminate the Darul Islam and encouraged its soldiers to surrender their weapons, ${ }^{102}$ and Zainal Arifin, member of the KNIP for Masyumi, accused the Dutch of using the Darul Islam for their own political gains. By inflating the threat posed by the Darul Islam, Arifin argued, the Dutch were trying to convince the Republic to agree to a longer-term Dutch military presence on Java. He described the Darul Islam as a 'self-defence movement against the despotic actions pursued by the Dutch Army' and a 'small issue' for the Republic. ${ }^{103}$ These statements further reinforced Zainal Arifin's earlier comment that 'the conflict between TNI and DI is military as much as political [...]; the DI problem is not a very difficult one, and if no third party interferes, we will solve it amongst ourselves'. ${ }^{104}$

One attempt to solve the Darul Islam problem peacefully at the local level had been the establishment of neighbourhood associations. The chiefs of these organizations, however, were elected, which created a system that 'fully collided with traditional adat institutions in West Java', according to the Dutch Secretary of State for domestic affairs. He also feared that with the current widespread presence of terrorist organizations in the territory, the chiefs could be exploited as a result of their being in control of both population and goods, thus leading to the creation of a structure 'too similar to those implemented by totalitarian regimes'. The cure, the Secretary of State concluded, would likely prove worse than the disease itself. ${ }^{105}$

Dutch reports from these weeks focused on the Darul Islam's violent means, even though at the same time some Republican officers continued to insist on the commonality of aims between TII and TNI. And although clashes between the two armies were still

100 'Moh. Natsir tentang Daroel Islam', Pewarta Surabaja, 7 September 1949; 'Moh. Natsir: Er is een Darul Islam, doch er is ook een valse Darul Islam', in Indonesisch pers en radio overzicht, Java, 6 September 1949.

101 'CMI Signalement de Negara Islam Indonesia', 21 October 1949, AAS no. 3979, NA.

102 'Republik tida aken berantas Daroel Islam', Sin Po, 19 September 1949.

103 'Membesarkan berita D.I. untuk keuntungan politik', Harian Berita, 21 September 1949.

104 'KNIP-leden bezoeken het gebied van Tjiamis', in Indonesisch pers en radio overzicht, Java, 9 September 1949.

105 'Oprichting buurtgenootschappen ter bestrijding Darul-Islam', 7 November 1949, AAS no. 3979, NA. 
taking place, ${ }^{106}$ the commander of the 3rd TNI division in West Priangan, Major Ardiwinata, stated in a letter addressed to Darul Islam troops stationed in Lamburawi: 'I am a member of TNI, but as a Muslim, I am proud of the Islamic spirit that burns in your hearts [...] The goals of the TNI, to tell the truth, are not different from the goals of the DI's fight, and it is not appropriate that we become each other's enemies [...] Don't we all want a government blessed by Allah and endorsed by the people?' ${ }^{107}$

In a military report written after the NII proclamation, the Darul Islam in West Java was described as a movement advancing Islamic democracy, opposing colonialist capitalism and complying with the Republic's authority. ${ }^{108}$ In 1951 another army report argued that in 1948-49 Colonel Sadikin and the Darul Islam shared the same goal of getting rid of the Dutch and ensuring Indonesia's independence. ${ }^{109}$

\section{CONCLUDING REMARKS}

The Dutch invasion and occupation of West Java in the second half of 1947 had the unexpected result of 'freeing' Kartosuwiryo from Soekarno's politics, allowing him - and West Java - to pursue a different path to independence. As West Java was declared Dutch territory, the Republican agenda - now decided upon in Yogyakarta - had become irrelevant to this region. Gradually Kartosuwiryo, Kamran, Oni and K.H. Gozali Toesi realized what they had imagined and planned for years: the embryo of an Islamic state of Indonesia. Throughout this chapter we have seen the idea of such a state and its structure evolving from the Garut-based 'Defence Council' to the regional network of MOIs, followed by the expansion of the latter's control across West Java and then into Central Java, to the eventual proclamation of the Negara Islam Indonesia with a constitution and a penal code.

106 Clashes were still taking place between Islamic and regular troops, as accounted in 'Report by TNI Siliwangi', 21 October 1949, AABRI DI no. 4; 'Lapuran mingguan bulan November', TNI Siliwangi, 7 December 1949, AABRI DI no. 8.

107 Letter from Major Ardiwinata, Commander of III D. West Priangan, to Darul Islam 'brothers' in Lamburawi, 26 September 1949, AABRI DI no. 3.

108 '1. Organisasi badan perdjuangan di Jawa Barat, 1945-1948', AABRI DI [n.d.].

109 'Verslag tugas penjelesaian DI Djawa Barat', 20 July 1951, AABRI DI no. 15.

Another perspective on the changed relationship between Kartosuwiryo and the Republic can be found in B. Elson and C. Formichi, 'Why did Kartosuwiryo start shooting?', Journal of Southeast Asian Studies 42-3 (October 2011): pp. 458-86. 
The Republic's reaction to Kartosuwiryo's actions is the parallel thread woven throughout this chapter and at the heart of the next. As encapsulated in Boland's and Kahin's statements, this relationship is generally understood as Darul Islam's opposition to the Republic. Post-independence state-controlled narratives, expounded in Chapter 6, also propagated the idea that, in the eyes of the Republican state, Kartosuwiryo and the Darul Islam were 'the enemy within'. However, it is quite clear their relationship was more complicated: in 1948 TNI and TII attempted to coordinate actions on the ground, TII commanders reached out to Republican ministers arguing they fought the same battle, and several Masyumi leaders in the Republic's territory were also inclined towards creating an Islamic state.

The separation of the political paths taken by the Pancasila Republic and the Islamic State in mid 1947 had helped smooth the edges of the secular nationalists and the religious factions. But the political re-unification of Java after the second Dutch invasion in December 1948 precipitated a situation in which Kartosuwiryo openly accused Soekarno of being a weak leader and a puppet of the colonial masters. Within the Republican ranks, commanders and politicians were not all of the same mind. Opposing military and political interests left the relationship between the Republic and the Darul Islam undefined throughout 1949 and well into the 1950 s, as we shall see in the next chapter. 